\title{
Structure and electrical properties of polymer electrolyte membrane for fuel cell application
}

\author{
Yusmaniar Yusmaniar ${ }^{1}$, Afrizal Afrizal ${ }^{1}$, Nurzaman $_{\text {Nurzaman }}^{2}$, and Erfan Handoko ${ }^{2, *}$ \\ ${ }^{1}$ Universitas Negeri Jakarta, Dept of Chemistry, Jalan Rawamangun Muka 13220, Jakarta, Indonesia \\ ${ }^{2}$ Universitas Negeri Jakarta, Dept of Physics, Jalan Rawamangun Muka 13220, Jakarta, Indonesia
}

\begin{abstract}
In this study to investigate the Polymer Electrolyte Membrane or Proton Exchange Membrane (PEM) that were synthesized by using acrilonitrile butadiene styrene (ABS). In order to enhance ability as a proton conductive polymer membrane as electrolyte, amorphous and crystalline silica ( $3 \%$ and $5 \%$ ) were added to the initial mixture of ABS to inhibit relatively high proton conductivity. The structural and morphological characterization of samples was done by X-ray powder diffractometer, FTIR and scanning electron microscopy. Electrical properties were determined by LCR-meter (HIOKI 3522-50LCR HiTESTER). The structure analysis shows that the ABS amorphous phase with the unsmoth surface. The electrical conductivity of Polymer Electrolyte Membrane is $4,21 \times 10^{-3} \mathrm{~S} / \mathrm{cm}$ of ABS with $5 \%$ amorphous silica.
\end{abstract}

\section{Introduction}

Currently world energy consumption levels are increasing while energy sources, especially energy derived from fossils, are increasingly depleting their existence [1-12]. In this regard, there are a few things to keep in mind in the search for alternative energy sources that is its ability to be widely used with low production cost and high efficiency $[13,14]$. One of the alternative energy candidates is quite promising and the center of attention of researchers today is fuel cell or known as proton exchange membrane fuel cell (PEMFC). PEMFC is a generating device that converts hydrogen and oxygen into electricity with low water and heat as a by-product so that technology is categorized as an environmentally friendly technology $[15,16]$. One of the components in the fuel cell is the electrolyte membrane which is the primary key in this technology. This is a challenge for the research team to develop the process of making Polymer Electrolyte Membrane Fuel Cell (PEMFC) based on ABS mixed with silica and carbon material by using spin casting system (SC) method to get membrane with uniform thickness which has efficiency high and has a high corrosion resistance and chemical and physical stability and density and shape that can be adjusted so that the application of this fuel cell can be used as a new alternative energy source that is really promising. In this study, polymer materials have been made as membranes so that they have superior physical and chemical properties compared to the previous materials. The material to be used for making Polymer Electrolyte Membrane Fuel Cell (PEMFC) is acrylonitrile butadiene styrene (ABS) or composite, this is because graphite has some superior properties including corrosion resistance, low weight, low contact resistance, stable both physically and chemically compared to metal [16].

\section{Experimental}

Preparation of Acrylonitrile Butadiene Styrene (ABS) membrane with silica composition of ABS as much as 1.5 gram, dissolved in $10 \mathrm{ml}$ methyl ethyl ketone and added amorphous and crystalline husk silica of $0 \%, 3 \%$ and $5 \%$ ABS ABS silica printed with a thickness of $100 \mu$ mdrying membrane in $50^{\circ} \mathrm{C}$ temperature oven for 48 hours. The results of white and glossy membrane sheets were characterized by a sulfonationprocess in a solution of $5 \mathrm{M}$ and $18 \mathrm{M}$ sulfuric acid for $24 \mathrm{H}$ at room temperature. Analysis of membrane structure with X-ray diffraction (XRD) Co Ka Phillips, Scanning Electron Microscope (SEM) Jeol and FT-IR Simadzu. The ionic conductivity test using LCR-meter (HIOKI 3522-50LCR HiTESTER) with membrane size $1 \mathrm{~cm} \mathrm{x} 1 \mathrm{~cm}$ was prepared.

\section{Results and discussion}

The results of x-ray diffraction measurements show that the polymer membrane does not form crystals after the printing and heating results in the oven. Based on the peak-shaped diffraction peak pattern, the polymer membrane is a non-crystalline material as shown in Fig. 1.

\footnotetext{
* Corresponding author: erfan@unj.ac.id
} 


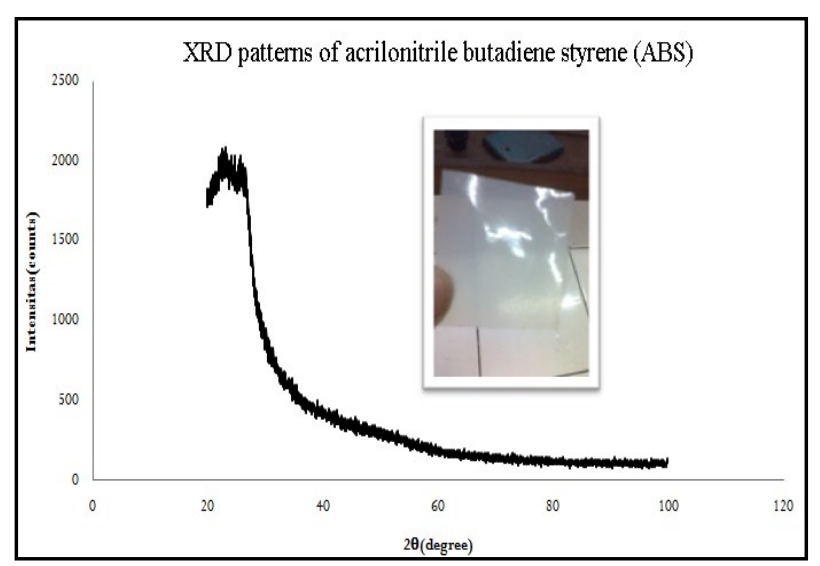

Fig 1. XRD pattern of membrane ABS.

The water uptake test is performed to determine the amount of water and methanol absorbed by the membrane by soaking for 24 hours. Samples were prepared with a size of $2 \mathrm{~cm} \times 2 \mathrm{~cm}$ and dried in an oven at $50^{\circ} \mathrm{C}$ for 8 hours. for sulfonated membrane of concentrated sulfuric acid and $5 \mathrm{M}$ of water uptake test results seen in Table 1 and 2. In ABS-Si 3\% amorphates have produced large uptake of water and methanol for sulphonated sulfuric membrane. While ABS-Si 5\% Crystalline for sulfonated sulfuric acid membrane $5 \mathrm{M}$ also produces large uptake for water and ABS-Si 0\% for alcohol.

Table 1. Water uptake test for sulphonated sulfuric membrane.

\begin{tabular}{|c|c|c|}
\hline Composition & $\begin{array}{c}\text { Methanol } \\
\text { Uptake }(\%)\end{array}$ & $\begin{array}{c}\text { Water Uptake } \\
(\%)\end{array}$ \\
\hline ABS-Si 0\% & 16,67 & 9,09 \\
\hline ABS-Si 3 \% Amorf & $\mathbf{8 5 7 , 1 4}$ & $\mathbf{1 2 3 6}$ \\
\hline ABS-Si 5\% Amorf & 516,39 & 404 \\
\hline ABS-Si 3 \% Kristalin & 18,18 & 20 \\
\hline ABS-Si 5\% Kristalin & $\mathbf{6 5 8 , 7 3}$ & $\mathbf{6 2 9 , 0 6}$ \\
\hline
\end{tabular}

Table 2. Water uptake test for sulphonated sulfuric membrane 5 M.

\begin{tabular}{|c|c|c|}
\hline Composition & $\begin{array}{c}\text { Methanol } \\
\text { Uptake }(\%)\end{array}$ & $\begin{array}{c}\text { Water Uptake } \\
(\%)\end{array}$ \\
\hline ABS-Si 0\% & 12,50 & 14,28 \\
\hline ABS-Si 3 \% Amorf & 10,81 & 12,12 \\
\hline ABS-Si 5\% Amorf & 7,14 & 4,76 \\
\hline ABS-Si 3 \% Kristalin & 8,10 & 25 \\
\hline ABS-Si 5\% Kristalin & 4,91 & 32,35 \\
\hline
\end{tabular}
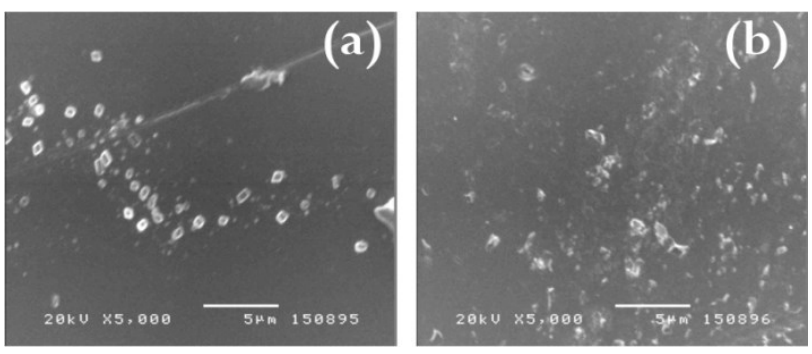

Fig 2. SEM image of membrane before desulfonation with $5 \%$ silica (a) crystalline and (b) amorphous.
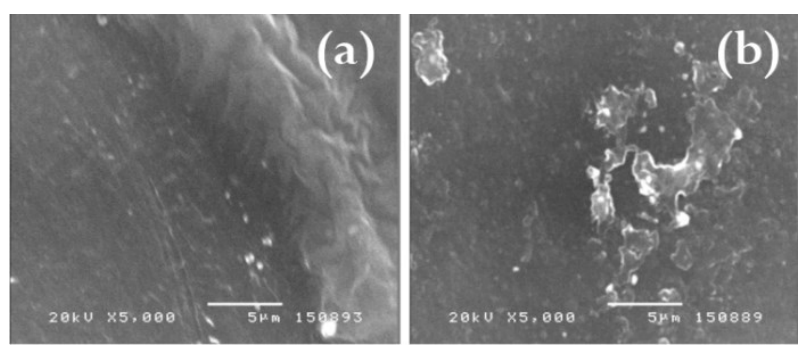

Fig. 3. SEM image of ABS without silica (a) disulfonated with $5 \mathrm{M}$ sulfuric acid and (b) disulfonated with concentrated sulfuric acid.

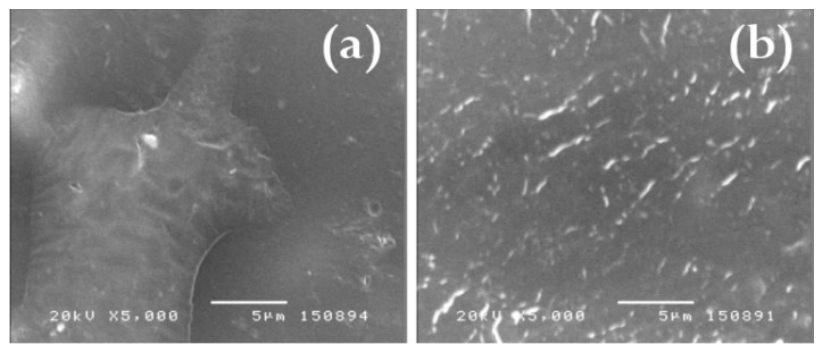

Fig. 4. SEM image of $1 \%$ crystal silica ABS SEM (a) before (b) after desulfonation with $5 \mathrm{M}$ sulfuric acid.

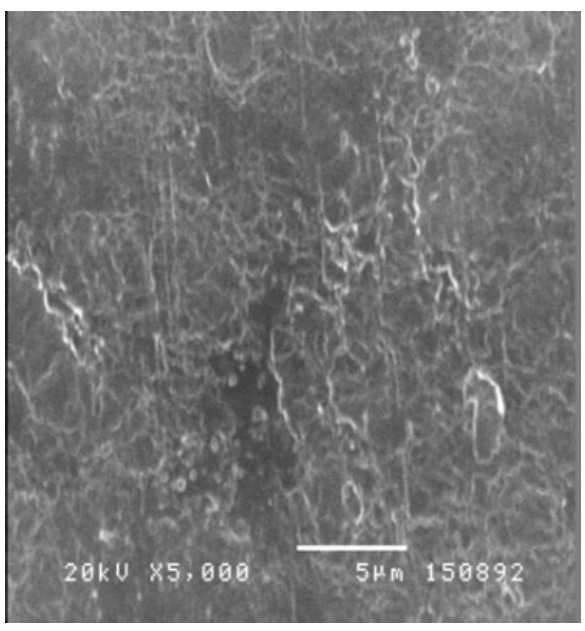

Fig. 5. SEM image of ABS crystal silica 3\% after desulfonation with concentrated sulfuric acid.

Fig. 2 shows SEM image of membrane ABS without sulphonated and unsulphonated (left) ABS sulfuric acid with $5 \mathrm{M}$ (left) sulfuric acid there is an air bubble still trapped in the membrane whereas after disulfonation with concentrated sulfuric acid there is more pore pore in the region which is darker. Fig.3 is an ABS SEM photo without silica (a) disulfonated with 5M sulfuric acid and (b) disulfonated with concentrated sulfuric acid. There has been a significant difference where ABS is tersufonasi with concentrated sulfuric acid more produces pores. Fig. 4 is the result of a $3 \%$ crystal silica ABS (a) before (b) after disulfonation with $5 \mathrm{M}$ sulfuric acid having formed pores due to the sulphonation process. Fig. 5 SEM image of $3 \%$ silica crystalline after disulfonation with concentrated sulfuric acid which produces more pores on the polymer membrane. 


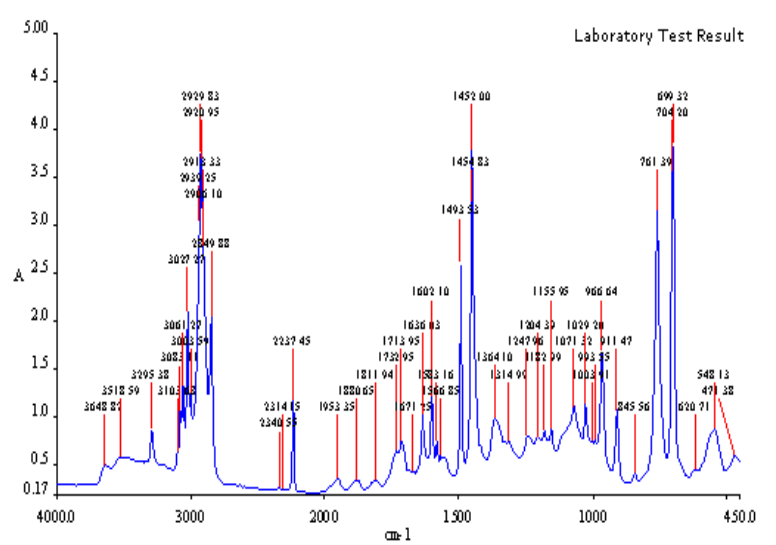

Fig. 6. FTIR membrane ABS spectra with 3\% sulfated silica crystals of $5 \mathrm{M}$. sulfuric acid.

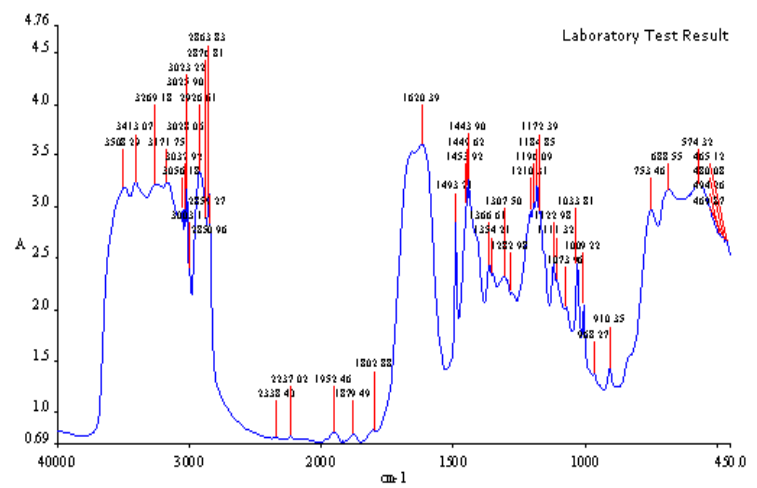

Fig. 7. FTIR membrane ABS spectra with $3 \%$ sulfonated crystal silica concentrated sulfuric acid.

Based on spectrum data ABS $3 \%$ can be seen in Fig. 6 indicating ABS sulfonated membrane (ABS) is known with absorption bands at wave number 3083.25-3003.59 $\mathrm{cm}^{-1}$. This shows the presence of an $\mathrm{OH}$ group which is $\mathrm{OH}$ in the sulfonate group. In addition, the presence of sulfonate groups is indicated by the absorption band symmetric strain $\mathrm{O}=\mathrm{S}=\mathrm{O} 1071.33 \mathrm{~cm}^{-1}$, strain $\mathrm{S}=\mathrm{O}$ $1029.2 \mathrm{~cm}^{-1}$ and S-O $761.41 \mathrm{~cm}^{-1}$. This proves that the sulfonation process has taken place. While on the sulphonate group is indicated by absorption band symmetric strain $\mathrm{O}=\mathrm{S}=\mathrm{O} 1073.96 \mathrm{~cm}^{-1}$, strain $\mathrm{S}=\mathrm{O}$ $1033.81 \mathrm{~cm}^{-1}$ and $\mathrm{S}-\mathrm{O} 753.46 \mathrm{~cm}^{-1}$. This proves that the sulphonation process in the concentrated sulfuric acid sample has also occurred.

Table 3. The electrical conductivity of Polymer Electrolyte Membrane.

\begin{tabular}{|c|c|c|}
\hline \multirow{2}{*}{ Addition of Silica } & \multicolumn{2}{|c|}{ Conductivity (S/cm) } \\
\cline { 2 - 3 } & $5 \mathrm{M}$ sulfuric acid & $\begin{array}{c}18 \mathrm{M} \text { Sulfuric } \\
\text { acid }\end{array}$ \\
\hline ABS-Si 0\% & $1,58 \times 10^{-5}$ & $3,44 \times 10^{-5}$ \\
\hline ABS-Si 3 \% Amorf & $3,28 \times 10^{-5}$ & $\mathbf{3 , 0 9 \times 1 0 ^ { - 3 }}$ \\
\hline ABS-Si 5\% Amorf & $7,68 \times \times 10^{-5}$ & $\mathbf{4 , 2 1 \times 1 0 ^ { - 3 }}$ \\
\hline ABS-Si 3\% Kristalin & $1,21 \times 10^{-5}$ & $1,70 \times 10^{-3}$ \\
\hline ABS-Si 5\% Kristalin & $2,25 \times 10^{-5}$ & $3,42 \times 10^{-4}$ \\
\hline
\end{tabular}

The addition of silica and the type of silica added to the ABS membrane and the concentration of sulfuric acid have an effect on the conductivity value. The value of water uptake is related to conductivity value. With so much water content it is easier for the sulfonate group to deliver protons in the form of proton dihidrat resulting in higher conductivity values. This is evidenced by the uptake of water in membranes having high conductivity value of $5 \% \mathrm{Si}-\mathrm{Si}$ silica. Sulfonated amorphous concentrated sulfuric acid with conductivity value of 4.21 $\mathrm{x} 10^{-3} \mathrm{~S} / \mathrm{cm}$ also has a high water absorption of $404 \%$. However, this conductivity value is still very low when compared to Nafion membrane that is $0.1 \mathrm{~S} / \mathrm{cm}$. The mechanical properties of sulphonated membranes with concentrated sulfuric acid are also very fragile and easily destroyed. This membrane cannot be applied to the fuel cell. While the sulphonated membrane with $5 \mathrm{M}$ sulfuric acid is much stronger but has a low conductivity value of $10^{-5} \mathrm{~S} / \mathrm{cm}$. This conductivity value is equivalent to a weaker insulator.

\section{Conclusions}

Synthesized ABS composite membrane added silica. The formed membrane does not have a crystal structure. The concentration of sulfuric acid influences the formation of sulphonate groups. Sulfuric acid with a concentration of 5 $\mathrm{M}$ can form sulphonate groups. While sulfuric acid with concentration $18 \mathrm{M}$ also forming a sulphonate group but destroying the membrane structure and making the membrane fragile. The best uptake and methanol uptake test results on sulfonated membrane by $5 \mathrm{M}$ sulfuric acid and $5 \%$ crystalline silica addition of $32.35 \%$ for water uptake and $4.29 \%$ for uptake methanol. The best conductivity assay results on the membrane with the addition of $5 \%$ disulfonated amorphous silica in $18 \mathrm{M}$ sulfuric acid with a conductivity value of $4.21 \times 10^{-3} \mathrm{~S} / \mathrm{cm}$.

This work was funded by PKUPT grant of Universitas Negeri Jakarta, Indonesia

\section{References}

1. E. A. Cho, U. Jeon, H. Y. Ha, S. Hong, and I. Oh, "Characteristics of composite bipolar plates for polymer electrolyte membrane fuel cells," vol. 125, pp. 178-182, (2004).

2. D. Chu and R. Jiang, "Performance of polymer electrolyte membrane fuel cell PEMFC/stacks Part I. Evaluation and simulation of an airbreathing PEMFC stack," pp. 128-133, (1999).

3. P. L. Hentall, J. B. Lakeman, G. O. Mepsted, J. M. Moore, and P. L. Adcock, "New materials for polymer electrolyte membrane fuel cell current collectors," pp. 235-241, (1999).

4. E. Hontanon, M. J. Escudero, C. Bautista, and L. Daza, "using computational fluid dynamics techniques," (2000).

5. S. Huang, P. Ganesan, S. Park, and B. N. Popov, "Development of a Titanium Dioxide-Supported Platinum Catalyst with Ultrahigh Stability for 
Polymer Electrolyte Membrane Fuel Cell Applications," pp. 13898-13899, (2009).

6. A. Kumar and R. G. Reddy, "Effect of channel dimensions and shape in the flow-field distributor on the performance of polymer electrolyte membrane fuel cells," vol. 113, pp. 11-18, (2003).

7. C. H. Lee, H. B. Park, Y. M. Lee, and R. D. Lee, "Importance of Proton Conductivity Measurement in Polymer Electrolyte Membrane for Fuel Cell Application," pp. 7617-7626, (2005).

8. Q. Li, R. He, J. O. Jensen, and N. J. Bjerrum, "Approaches and Recent Development of Polymer Electrolyte Membranes for Fuel Cells Operating above," pp. 4896-4915, (2003).

9. M. A. Rodrigo, J. J. Linares, and G. Manjavacas, "Synthesis and characterisation of electrolyte membrane for high temperature PEMFCs," vol. 280, pp. 351-362, (2006).

10. V. Neburchilov, J. Martin, H. Wang, and J. Zhang, "A review of polymer electrolyte membranes for direct methanol fuel cells," vol. 169, pp. 221-238, (2007).

11. J. Dodelet, "density in polymer electrolyte membrane fuel cells," (2011).

12. N. Rajalakshmi, H. Ryu, M. M. Shaijumon, and S. Ramaprabhu, "Performance of polymer electrolyte membrane fuel cells with carbon nanotubes as oxygen reduction catalyst support material," vol. 140, pp. 250-257, (2005).

13. K. D. Kreuer, "On the development of proton conducting polymer membranes for hydrogen and methanol fuel cells," vol. 185, pp. 29-39, (2001).

14. H. Wang and J. A. Turner, "Ferritic stainless steels as bipolar plate material for polymer electrolyte membrane fuel cells," vol. 128, pp. 193-200, (2004).

15. F. Yuan and H. Ryu, "The synthesis, characterization, and performance of carbon nanotubes and carbon nanofibres with controlled size and morphology as a catalyst support material for a polymer electrolyte membrane fuel cell," vol. 596.

16. B. Smitha, S. Sridhar, and A. A. Khan, "Solid polymer electrolyte membranes for fuel cell applications - a review," vol. 259, pp. 10-26, (2005). 